\title{
Weed Management during Pasture Establishment ${ }^{1}$
}

\author{
Brent Sellers, Pratap Devkota, Joao Vendramini, and Marcelo Wallau²
}

\section{Introduction}

Pasture establishment is an expensive venture, and it is important to get the forage growing as quickly and vigorously as possible. In addition to good soil conditions, weed management is necessary to encourage rapid forage growth. This publication details techniques for chemical weed control prior to and during pasture establishment and is intended for county Extension faculty as well as owners and managers of grazing lands.

The soil is full of weed seeds, commonly referred to as a soil seed bank. In pastures that needrenovation, weed control during and after pasture establishment will likely be necessary. This is true even for pastures that were relatively weed-free prior to renovation.

The first step in pasture renovation includes removing the existing vegetation. In most cases, 3-4 qt/acre of glyphosate will kill all living plant material, except for woody species. For some species, such as palmetto, more drastic measures are necessary. Once the plant material is dead, it will be necessary to till the pasture repeatedly, first with a moldboard plow, followed by repeated disking and/or rotovating. Repeated tillage is necessary to prepare a clean, weed-free seed bed prior to planting. If tillage applications are spaced 2-3 weeks apart, many weeds will germinate from seed, then be destroyed by subsequent tillage operations. This repeated tillage will help to deplete the soil seed bank.

The next step entails planting the desired forage. UF/IFAS has detailed instructions for establishing forage grasses. See EDIS publication SS-AGR-161, Forage Planting and Establishment Methods on Prepared Seedbed (https://edis. ifas.ufl.edu/ag107) or consult your local UF/IFAS Extension agent for recommendations.

Most weeds will emerge shortly after the grass has been planted. Therefore, time is of the essence for weed control operations. In most cases, sedges tend to be the most problematic, but broadleaf weeds can quickly become established as well.

The best weed control strategies for each pasture grass are outlined below.

1. This document is SS-AGR-287, one of a series of the Agronomy Department, UF/IFAS Extension. Original publication date October 2007. Revised October 2010, September 2011, and August 2021. Visit the EDIS website at https://edis.ifas.ufl.edu for the currently supported version of this publication.

2. Brent Sellers, professor, Agronomy Department, UF/IFAS Range Cattle Research and Education Center; Pratap Devkota, assistant professor, Agronomy Department, UF/IFAS West Florida REC; Joao Vendramini, professor and forage specialist, Agronomy Department, UF/IFAS RCREC; and Marcelo Wallau, forage Extension specialist and assistant professor, Agronomy Department; UF/IFAS Extension, Gainesville, FL 32611. Jason Ferrell, professor, UF/IFAS Agronomy Department was one of the original authors.

The use of trade names in this publication is solely for the purpose of providing specific information. UF/IFAS does not guarantee or warranty the products named, and references to them in this publication do not signify our approval to the exclusion of other products of suitable composition.

All chemicals should be used in accordance with directions on the manufacturer's label.

The Institute of Food and Agricultural Sciences (IFAS) is an Equal Opportunity Institution authorized to provide research, educational information and other services only to individuals and institutions that function with non-discrimination with respect to race, creed, color, religion, age, disability, sex, sexual orientation, marital status, national origin, political opinions or affiliations. For more information on obtaining other UF/IFAS Extension publications, contact your county's UF/IFAS Extension office. U.S. Department of Agriculture, UF/IFAS Extension Service, University of Florida, IFAS, Florida A \& M University Cooperative Extension Program, and Boards of County Commissioners Cooperating. Nick T. Place, dean for UF/IFAS Extension. 


\section{Bahiagrass (Argentine, Pensacola, Tifton-9, etc.)}

Herbicides should not be applied to young bahiagrass seedlings. Apply herbicides only after bahiagrass has at least 6 inches of growth. Repeated mowing is the only option for suppressing weeds during bahiagrass establishment.

\section{Bermudagrass (Florakirk, Jiggs, Tifton-85)}

Apply 2 pt/acre of WeedMaster (or any other product containing 2,4-D + dicamba) 7-10 days after planting. Diuron is another herbicide that is useful for controlling crabgrass and other weeds, but sprigs must be planted 2 inches deep. Apply Diuron at 2 quarts/acre. Do not apply Diuron if you are planting tops and crimping material into the soil because it will cause severe injury. Outrider (sulfosulfuron) herbicide may be applied at 1.0-1.33 oz/acre no earlier than 4 weeks after planting.

\section{Stargrass (Florico, Florona, Okeechobee, Ona)}

Apply 2 pt/acre of WeedMaster or any other product containing 2,4-D + dicamba 7-10 days after planting. Alternatively, apply $0.78 \mathrm{lb} 2,4-\mathrm{D}$ with $0.22 \mathrm{lb}$ of dicamba. Outrider (sulfosulfuron) herbicide may be applied at 1.0-1.33 oz/acre no earlier than 4 weeks after planting.

\section{Limpograss (Floralta)}

Apply $0.75 \mathrm{lb} / \mathrm{acre}$ of dicamba 7-10 days after planting. There are several dicamba-containing products. Outrider (sulfosulfuron) herbicide may be applied at $1.0-1.33 \mathrm{oz} /$ acre no earlier than 4 weeks after planting. Limpograss is sensitive to 2,4-D applications; the herbicide has been shown to kill limpograss when applied soon after planting.

\section{Conclusion}

In all cases, it is best to apply herbicides within the 7- to 10day window after planting. If herbicides are applied within this period, pasture establishment will occurmore quickly than it would without herbicide applications. If this window of opportunity is missed, Outrider at $1.0-1.33 \mathrm{oz} / \mathrm{acre}$, plus 2,4-D + dicamba at the above rates should provide excellent weed control. Do not use Outrider on seedling bahiagrass, or complete kill will occur; however, it is safe on established bahiagrass. 